\title{
Lamotrigine Associated DRESS Syndrome - a Case Report
}

\author{
Jagoda BALABAN ${ }^{1 *}$, Đuka NINKOVIĆ-BAROŠ ${ }^{1}$ \\ ${ }^{1}$ Clinic of Dermatovenereology, University Hospital Clinical Centre of Banja Luka, Republic of Srpska, Bosnia and \\ Herzegovina
}

*Correspondence: Jagoda Balaban, E mail: jagoda.balaban@yahoo.com

UDK 616-097-02:615.213/214.06

\section{DE GRUYTER OPEN}

\begin{abstract}
Drug-induced delayed multiorgan hypersensitivity syndrome, also known as drug rash (reaction) with eosinophilia and systemic symptoms (DRESS) syndrome, represents a drug-induced cluster of skin, hematologic and systemic symptoms. More than forty drugs have been associated with this syndrome. We present a case of DRESS syndrome suspecting that lamotrigine was directly responsible for the patient's rash and other symptoms. A female patient presented with extensive skin rash, fever, hematologic abnormalities, organ involvement such as hepatitis, pancreatitis and respiratory symptoms. The symptoms developed four weeks after the initiation of the offending drug, and disappeared eight weeks after its discontinuation.
\end{abstract}

\section{Key words}

Drug Hypersensitivity Syndrome; Anticonvulsants; Drug-Related Side Effects and Adverse Reactions; Antipsychotic Agents; Case Reports

$\mathrm{D}$ rug-induced delayed multiorgan hypersensitivity syndrome (DIDMOHS) (1), also known as drug rash (reaction) with eosinophilia and systemic symptoms (DRESS) syndrome, is a severe, unexpected drug reaction which affects several organ systems at the same time $(2,3,4)$. Most commonly it causes a combination of high fever, morbiliform skin rash and inflammation of one or more internal organs including the liver, kidneys, lungs and/or heart. It generally starts two to eight weeks after taking the offending medicine. The drugs most often reported with DRESS include anticonvulsants (particularly those with aromatic structures), sulfa derivatives, antidepressants, non-steroidal anti-inflammatory drugs, and antimicrobials $(5,6,7)$.

\section{Case report}

We present a 44-year-old unemployed nurse with psychiatric history since her teens. She was first admitted to the Emergency Department seven days before admission to our Clinic, because of persistent symptoms of high fever (body temperature above $38^{\circ} \mathrm{C}$ ), severe nonproductive cough, nasal secretion, facial swelling, especially around the nose, and erythema on the hands. A differential white blood cell count and urinalysis were performed, and except mild eosinophilia of $6 \%$ (normal range $0-5 \%$ ) all other findings were within normal limits. She was advised to stop taking all drugs. The patient was using three drugs (olanzapine: an antipsychotic serotonin blocker; lamotrigine: an antiepileptic and mood stabilizer; and losartan: an antihypertensive and angiotensin II receptor blocker), since she was discharged from the Clinic of Psychiatric Diseases a month before, where she was hospitalized under the diagnosis of paranoid personality disorder. Due to persistent high temperature and worsening of respiratory symptoms, the patient was examined by the specialist for infectious diseases, who set the diagnosis of acute bronchiolitis, and introduced azithromycin $500 \mathrm{mg}$ once daily 
during three days; the chest X-ray was normal and the patient was advised to visit a dermatologist. At the first dermatological examination, the patient had diffuse facial flushing with mild edema, and morbiliform skin rash mainly on the extremities. In addition to azithromycin, an antihistamine levocetirizine was introduced. In spite of the therapy, the skin rash was spreading, therefore hospitalization was recommended. On admission, the dermatology examination revealed diffuse erythematous and slightly edematous face, generalized maculopapular livid erythematous rash partly confluent on the trunk and extremities involving more than $50 \%$ of the body surface (Figures 1,2). No peripheral lympadenomegaly was detected.

\section{Laboratory and other relevant findings}

Laboratory findings on admission were as follows: erythrocyte sedimentation rate (ESR) $-13 \mathrm{~mm} / \mathrm{h}$, C-reactive protein (CRP) - $4.7 \mathrm{mg} / \mathrm{L}$ (normal range: 0 $-5 \mathrm{mg} / \mathrm{L}$ ), white blood cell count (WBC) - $17.3 \times 10^{9} / \mathrm{L}$ (normal range: $3.4-9.3 \times 10^{9} / \mathrm{L}$ ), red blood cell count $(\mathrm{RBC})-4.1 \times 10^{12} / \mathrm{L}$ (normal range: 3.9 - 5.4 $\mathrm{x} 10^{12} / \mathrm{L}$ ), platelets $(\mathrm{PLT})-246 \times 10^{3} / \mathrm{L}$ (normal range: $140-400 \times 10^{9} / \mathrm{L}$ ), differential white blood cell count: neutrohils $-6.46 \mathrm{x} \times 10^{\%} / \mathrm{L}$ or $38.2 \%$ (normal range: 2 $-7.5 \times 10^{9} / \mathrm{L}$ or $\left.50-75 \%\right)$, lymphocytes $-5.67 \times 10^{9} / \mathrm{L}$ or $32.8 \%$ (normal range: $0.8-4 \times 10 \% / \mathrm{L}$ or $20-40 \%$ ), monocytes $-0.9 \times 10 \% / \mathrm{L}$ or $5.4 \%$ (normal range: 0.08 - $1 \times 10^{\%} / \mathrm{L}$ or $\left.2-10 \%\right)$, eosinophils $-2.38 \times 10^{9} / \mathrm{L}$ or $13.8 \%$ (normal range: $0-0.5 \times 10 \%$ L or $0-5 \%$ ), basophils $-0.33 \times 10^{9} / \mathrm{L}$ or $1.9 \%$ (normal range: 0 -

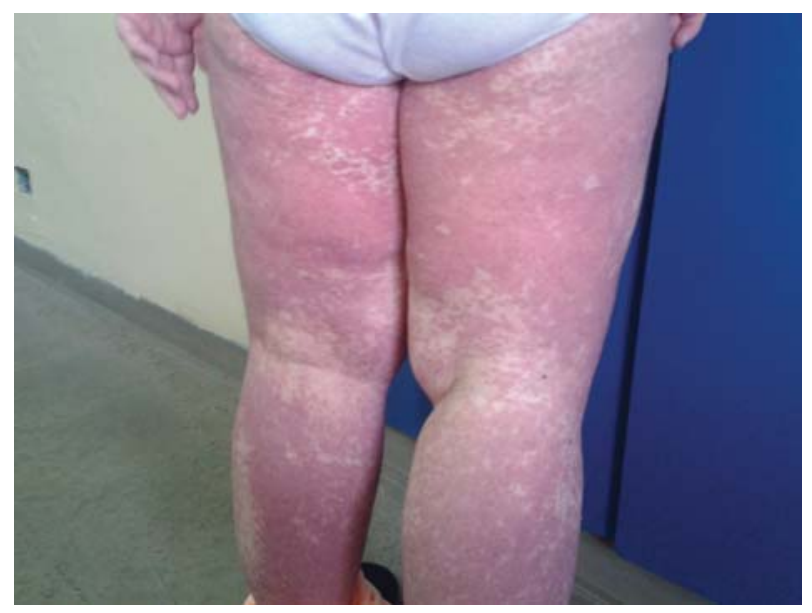

Figure 1. Maculopapular rash on admission
$0.1 \times 10^{9} / \mathrm{L}$ or $\left.0-1 \%\right)$, total bilirubin $-8.2 \mu \mathrm{mol} / \mathrm{L}$ (normal range: $3-21 \mu \mathrm{mol} / \mathrm{L}$ ), direct bilirubin - 2.0, $\mu \mathrm{mol} / \mathrm{L}$ (normal range: $0.1-5.2 \mu \mathrm{mol} / \mathrm{L}$ ), aspartate aminotransferase (AST) - $52 \mathrm{IU} / \mathrm{L}$ (normal range: 0 - 35 IU/L), alanine aminotransferase (ALT) - 136 U/L (normal range: $(0-35 \mathrm{U} / \mathrm{L})$, gamma glytamil transferase - $24.4 \mathrm{U} / \mathrm{L}$ (normal range: 1 - $38 \mathrm{U} / \mathrm{L}$ ), creatine kinase - $65 \mathrm{U} / \mathrm{L}$ (normal range: $24-170$ $\mathrm{U} / \mathrm{L}$ ), urea $-5.2 \mu \mathrm{mol} / \mathrm{L}$ (normal range: $2.5-7.5$ $\mu \mathrm{mol} / \mathrm{L}$ ), creatnine - $72 \mu \mathrm{mol} / \mathrm{L}$ (normal range: 44 $98 \mu \mathrm{mol} / \mathrm{L}$ ), serum amylase - $79 \mathrm{U} / \mathrm{L}$ (normal range: 20 - $118 \mathrm{U} / \mathrm{L}$ ), urine amylase - $601 \mathrm{U} / \mathrm{L}$ (normal range: $20-118 \mathrm{U} / \mathrm{L}$ ), lipase - 48U/L (normal range: 0 - $160 \mathrm{U} / \mathrm{L}$ ), urinanalysis was normal, ELISA herpes simplex virus typus 1 (HSV-1) IgM and IgG negative, HSV-2 IgM and IgG negative, anti Epstein-Barr virus (EBV) IgM negative, anti-EBV IgG 1.54 (positive > 1.1), anti cytomegalovirus (CMV) $\operatorname{IgM}$ and $\operatorname{IgG}$ negative. Peripheral blood smear: eosinophils - 15\% (normal range: $0-5 \%$ ), atypical lymphocytes - 8\% (normally $5 \%$ ), immature myelocytes (1\%). The upper abdomen ultrasound was normal. On the third day of hospitalization, the abnormal laboratory findings improved: WBC $10.5 \times 10^{9} / \mathrm{L}$, eosinophils 8.8\%, AST $15 \mathrm{IU} / \mathrm{L}$, ALT $50 \mathrm{IU} / \mathrm{L}$.

The diagnosis of DRESS syndrome was established based on the diagnostic criteria for DRESS syndrome, including skin rash, blood count and laboratory abnormalites that were as follows: leukocytosis (>11x109/L), eosinophilia (>1.5x109/L), atypical lymphocytes $(>5 \%)$ and liver abnormalities $($ ALT $>100$ IU/L) $(6,8)$.

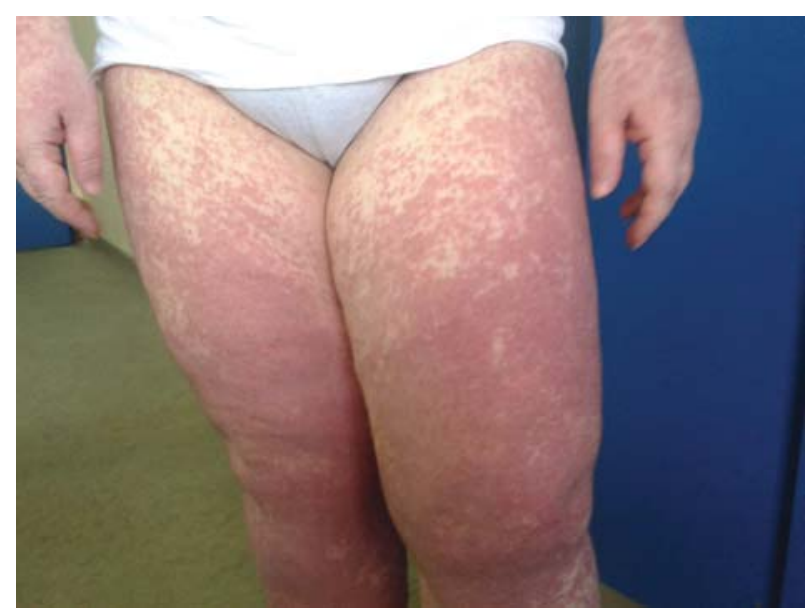

Figure 2. Maculopapular rash on admission 


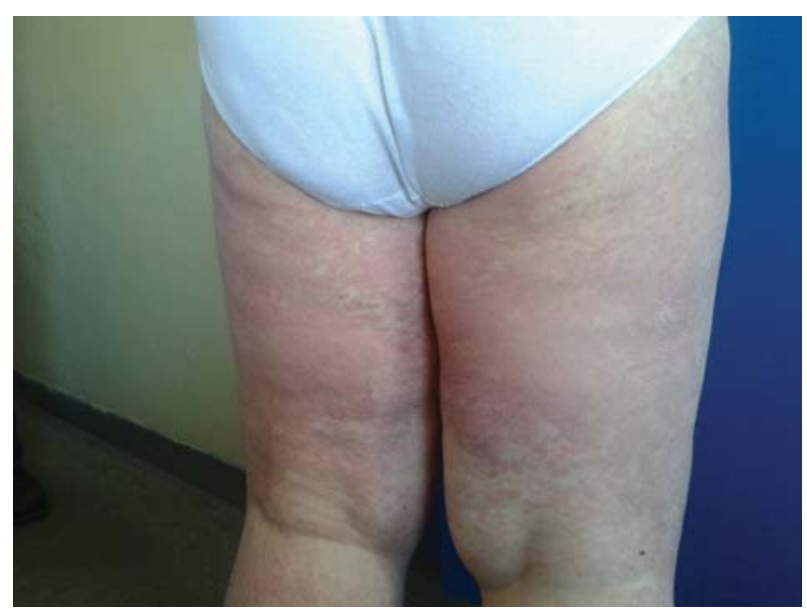

Figure 3. Maculopapular rash 2 weeks after the withdrawal of lamotrigine and olanzapine

During the seven-day hospital stay, the patient received $40 \mathrm{mg}$ methylprednisolone daily, a systemic steroid, and oral ranitidine, loratadine; - an antihistaminic, butamirate citrate - an antitussic, and losartan - an antihypertensive. After being discharged, the patient continued oral corticosteroid therapy with $40 \mathrm{mg}$ prednisolone daily, with dose reduction by $10 \mathrm{mg}$ after every seven days. She continued taking ranitidine and losartan. On discharge, she still presented with erythematous macular rush. Three weeks later, laboratory findings (WBC with differential count, RBC, AST, ALT, urinanalysis and serum amylase) normalized, but the pale residual pinkish macular skin rash was still persistent (Figures 3 - 6). On last visit, six weeks after hospitalization

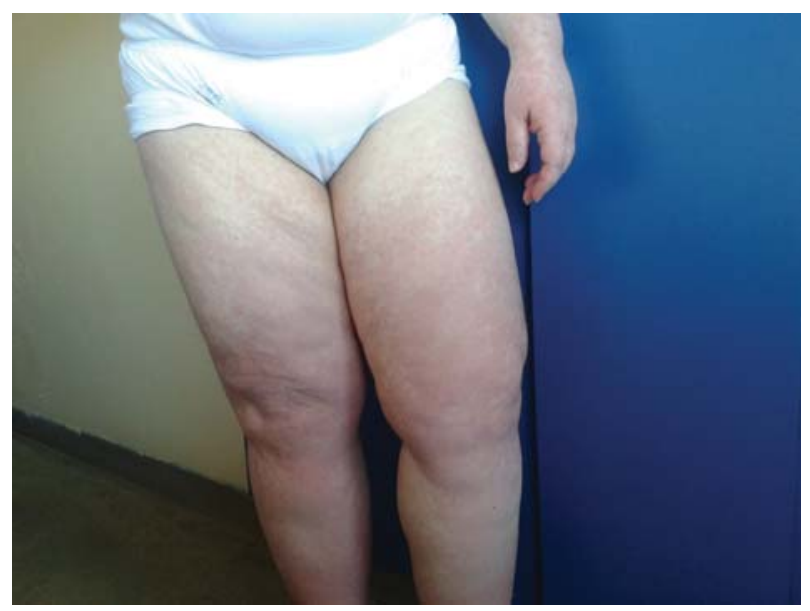

Figure 4. Maculopapular rash 2 weeks after the withdrawal of lamotrigine and olanzapine

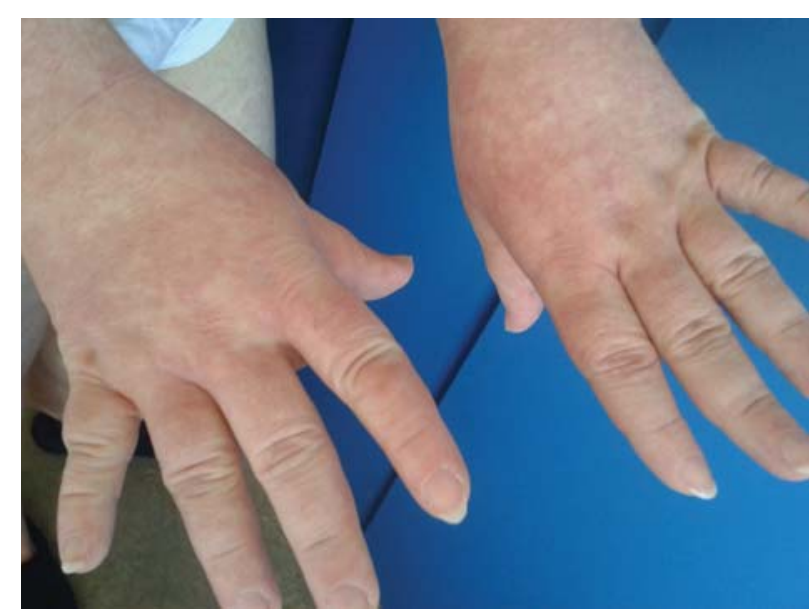

Figure 5. Maculopapular rash 2 weeks after the withdrawal of lamotrigine and olanzapine

and 8 weeks after lamotrigne and olanzapine were discontinued, the skin lesions completely resolved. Due to the psychiatrist's recommendation, olanzapine was reintroduced into the therapy, and since then the patient has been taking it without any problems.

\section{Discussion}

Before 1996, when Bouquet and associates described the DRESS syndrome, several different terms have been used such as: anticonvulsant hypersensitivity syndrome, first described in 1936 during the treatment with anticonvulsant drugs; drug hypersensitivity syndrome; drug-induced hypersensitivity syndrome $(9,10,11)$. The " $R$ " was previously used to indicate "rash" (9), now it indicates "reaction" (3).

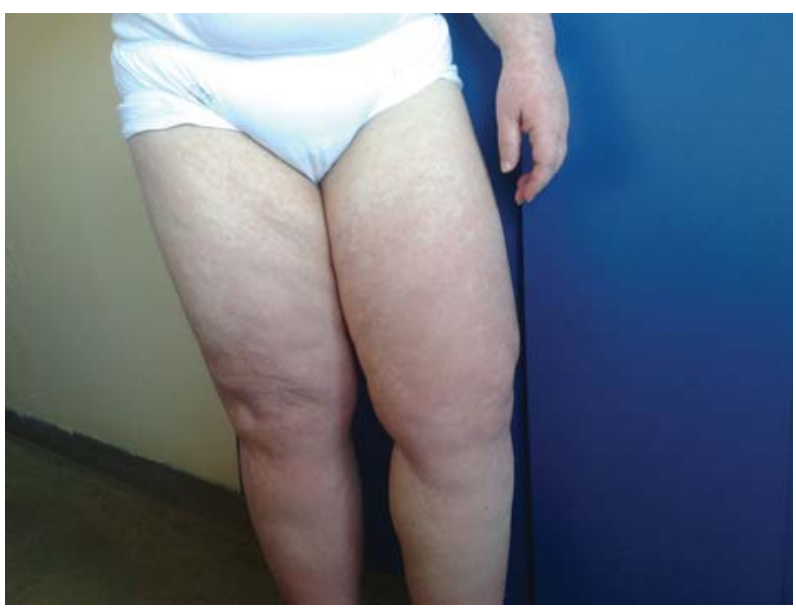

Figure 6. Maculopapular rash 2 weeks after the withdrawal of lamotrigine and olanzapine 
Though DRESS syndrome was recognized as a serious form of skin drug adverse reaction from the very beginning, it is currently viewed as a drug-related syndrome with life-threatening organ dysfunctions. A long interval from first drug exposure to symptom onset and a prolonged course after discontinuation of the offending drug even with flares, represent the two highly typical features of the syndrome (12). The syndrome is also characterized by an extensive rash, fever, lymphadenopathy, hematologic abnormalities, hepatitis, and involvement of the kidneys, lungs, heart, or pancreas. Although skin lesions may rapidly aggravate from erythematous to purpuric, pustrular or turn to exfoliative dermatitis, they can be overshadowed by the severity of organ involvement, hence "reaction" instead of "rash" in the acronym DRESS (13). The onset of symptoms is often delayed, occurring $2-8$ weeks after drug initiation (14). In our patient symptoms occurred one month after initiation of three drugs, two of which being psychoactive (olanzapine - antipsychotic serotonin blocker; lamotrigine - antiepileptic and mood stabilizers; and losartan - antihypertensive and angiotensin II receptor blockers).

The incidence of DRESS has been estimated to be between 1 in 1,000 and 1 in 10,000 drug exposures. It carries a mortality rate of $10-20 \%$, with most fatalities due to liver failure (15).

The exact pathogenesis of DRESS syndrome is not yet well understood. Although it is considered an idiosyncratic reaction, three potential causative factors have been identified among multiple cases: 1) a defect in drug metabolism resulting in the failure to eliminate toxic reactive intermediates (e.g. slow acetylation and defects in enzymes responsible for drug metabolism such as arene oxidase for anticonvulsants); 2) reactivation of human herpes virus-6 (HHV-6), human herpes virus-7 (HHV-7), Epstein-Barr virus (EBV), or cytomegalovirus (CMV), which may act as a trigger for the immune reaction; 3 ) or genetic predisposition that alters immune response $(4,16,17)$.

Two groups have developed specific criteria for making the diagnosis of DRESS syndrome: The European Registry of Severe Cutaneous Adverse Reactions Group (The RegiSCAR group) and Japanese Consensus Group (SCAR-J). The RegiSCAR study group developed a set of inclusion criteria (Table 1) and established a scoring system (total score ranges from 4 to 9), for classifying DRESS cases as definitive with final score $>5$, probable with final score $4-5$, possible with final score $2-3$, and no case with final score $<2$ (8).

According to RegiSCAR group criteria, our patient met all criteria except lymphadenopathy and reduced platelets. According to the RegiSCAR group scoring system, eosinophilia (>1.5x109/L), atypical lymphocytes ( $>5 \%)$, skin involvement $(>50 \%)$, suggestive skin rash, and liver abnormalities (ALT $>100$ IU/L) were scored as $2+1,+1,+1$, and +1 , respectively (8). Since the final score was +6 , the diagnosis of DRESS syndrome was definite in our patient.

According to the Japanese Consensus Group criteria for DRESS syndrome, our patient fulfilled the first five, thus being classified as having atypical DRESS syndrome (Table 2) (6). In comparison to criteria developed by the RegiSCAR group, the major difference was inclusion of HHV-6 reactivation (6). However, the use of HHV-6 reactivation as a criterion is controversial, because no definite evidence of the causative role of herpes viruses in DRESS syndrome has been reported (18). In the in vitro studies, it was found that drugs associated with DRESS syndrome do not only potentiate HHV-6 and EBV replication by inhibition of epigenetic control mechanisms (the two main are methylation and histone acetylation), but also induce an antiviral T-cell immune response in individuals with genetic susceptibility factors, by interacting with the major histocompatibility complex receptor (12). Since anticonvulsant drugs can induce hypogammaglobulinemia, it has been hypothesized that use of drugs associated with DRESS syndrome may promote viral reactivation by inducing immunosuppression. However, the mechanism underlying the direct drug-virus interaction remains unknown. Only a minority of transplant recipients with marked viral reactivation develop systemic manifestations. The systemic manifestations are suggested to be related to a strong immune response against the reactivated virus. Thus, DRESS syndrome, develops only in patients with both marked viral reactivation and an ability to produce a strong antiviral immune response (e.g. genetic polymorphisms for cytokines, receptors, or antagonists (as demonstrated for the TNF-receptor) (12). Meanwhile, Japanese criteria are less practical in routine clinical practice, 
Table 1. RegiSCAR criteria for diagnosisof DRESS syndrome (published by RegiSCAR

\section{All criteria fulfilled}

\section{Hospitalization}

2. Reaction suspected to be drug-related

3. Acute rash

\section{Three of the following four criteria}

4. Fever $>38^{\circ} \mathrm{C}$

5. Enlarged lymph nodes at least at 2 sites

6. Involvement of at least 1 internal organ

7. Blood count abnormalities - defined either by:

o Lymphocytes above or below normal limits ; or

o Eosinophils above the laboratory limits; or

o Platelets below the laboratory limits

as viral serologic tests are unhelpful (18). Quantitative PCR of the whole blood must be used in order to detect viral reactivations (12).

The liver is the most commonly involved organ in DRESS syndrome, and hepatitits, present also in our patient, occurs in about $80 \%$ of all cases (19, $20,21)$. The degree of hepatitis is related to the interval between the onset of the syndrome and the discontinuation of the offending drug. Apart from the liver, another, most frequently affected organs are the kidneys in $40 \%$ and lungs in 33\% of cases. Cardiovascular symptoms develop in $15 \%$ of cases, and pancreas is involved in about $5 \%$ of cases (22). The most common hematologic disorders that occur in DRESS syndrome are as follows: atypical lymphocytes (63\%), eosinophilia (52\%), lymphocytopenia (45\%), and thrombocytopenia $(25 \%)(23,24)$. Our patient had leukocytosis $\left(>11 \times 10^{9} / \mathrm{L}\right)$, eosinophilia $(>1.5 \mathrm{x}$ $10^{9}$ ) and atypical lymphocytosis (>5\%).

The outcome is usually favorable after discontinuation of the casual drug, although full symptom resolution requires at least two weeks and flares may occur. Moreover, after prompt withdrawal of the offending agent, complete resolution of skin lesions and visceral injury can be achieved in up to several weeks, which happened after 8 weeks in our patient. Although in less severe cases resolution can be achieved by using only supportive measures, in cases with internal organ impairment, moderate to high doses of corticosteroids should be commenced, but not before infection has been carefully ruled out! Corticosteroids should be gradually tapered over a period of $6-8$ weeks as in our patient, in order to prevent relapse which may occur especially with rapid discontinuation. Time to onset is shorter after rechallenge with the same drug.

There are more than 40 drugs, including lamotrigine and olanzapine, that have been reported to be associated with DRESS syndrome (18). Aromatic anticonvulsants (phenytoin, phenobarbital, carbamazepine) and sulphonamides are the most common causative drugs, but a variety 
Table 2. Japanese group's criteria for diagnosis*** of DRESS syndrome

1. Maculopapular rash developing $>3$ weeks after initiation of the suspected drug

2. Prolonged clinical symptoms: 2 weeks after discontinuation of the suspected drug

3. Fever $>38^{\circ} \mathrm{C}$

4. Liver abnormalities (alanine aminotransferase $>100 \mathrm{U} / \mathrm{L}$ )

5. Blood count abnormalities - defined either by:

o Lymphocytes above or below normal limits; or

o Eosinophils above the laboratory limits; or

o Platelets below the laboratory limits

6. Lymphadenopathy
7. Human herpes virus- 6 reactivation
*The diagnosis of typical syndrome is confirmed by the presence of all 7 criteria
${ }^{* *}$ The diagnosis of atypical syndrome is confirmed by the presence of the first 5 criteria

of other drugs have been reported such as: dapsone (DDS, 4,4-diaminodiphenylsulphone), allopurinol, captopril, calcium-channel blockers, ranitidine, thalidomide, minocycline, sulfasalazine, non-steroidal antiinflammatory agents, antituberculotic drugs, $\alpha$-methyldopa and antiretroviral drugs (abacavir, zalcitabine, nevirapine) (18, 20-27). Lamotrigine [6-(2,3-dichlorophenyl)-1,2,4-triazine-3,5-diamine] is an antiepileptic drug, used in the management of a broad range of seizures in adults and children which is not an aromatic antiepileptic, thus being structurally and pharmacologically unrelated to other antiepileptic medications e.g. carbamazepine $(28,29)$. Lamotrigine has been repoted in association with severe skin rash, multiorgan failure, DRESS syndrome, acute hepatic failure, and disseminated intravascular coagulation. Severe rashes due to lamotrigine occurr almost regularly within the first $6-8$ weeks of exposure, rarely after 12 weeks and almost exclusively later (30). Several reports of lamotrigine-induced DRESS syndrome have been reported in the literature (12, $27,28,29,31-34)$. The second psychoactive drug our patient was taking in combination with lamotrigine was an antipsychotic - olanzapine, an oxazepine that is prescribed to patients with schizophrenia or recurrent bipolar disorder. Regarding cutaneous adverse drug reactions due to olanzapine, the literature contains few reports of DRESS syndrome, contrary to lamotrigine that has commonly been reported as a causative agent in DRESS syndrome. Actually, in a frequently cited review on DRESS syndrome published in 2011 by Cacoub et al, only one case involved olanzapine (35). Since then, according to available literature, there are four new published cases of DRESS syndrome associated with olanzapine (12, 36-38). Although drug-drug interactions have been reported between antiepileptic and antipsychotic drugs, there was only one report of cross-sensitization between carbamazepine (aromatic antiepileptic drug) and olanzapine (aromatic antipsychotic drug) (38).

The diagnosis of DRESS syndrome in our case was definite. However, regarding causality, due to the scoring system established by Naranjo et al, it was a probable adverse drug reaction caused by lamotrigine (final score 7); we did not confirm the adverse event by at least one objective evidence e.g. by skin testing (39). Skin tests can assist in the causality assessment, but performed at a time distance from the DRESS 
syndrome episode (12). Given the fact that lamotrigine, opposed to olanzapine, is known as a common cause of DRESS syndrome, that there is no cross reactivity between them, and there was a necessity of its use in the given moment, the psychiatrist considered that olanzapine should be reintroduced into the therapy. If the psychiatrist had not reintroduced olanzapine into the therapy, patch testing would be performed in 6 months, and olanzapine would gradually be reintroduced under hospital supervision. Therefore, now we can only hypothesize that lamotrigine was directly responsible for our patient's rash, and all other symptoms and signs.

\section{Conclusion}

We present a case of a female patient who was treated with an antipsychotic - olanzapine in combination with an anticonvulsant - lamotrigine. Since both drugs were discontinued due to the development of DRESS syndrome, and with regard to the chronology of events, lamotrigine was considered the main suspected drug.

\section{Abbreviations}

DRESS - drug rash (reaction) with eosinophilia and systemic symptoms

DIDMOHS - drug-induced delayed multiorgan hypersensitivity syndrome

ESR - erythrocyte sedimentation rate

CRP - C-reactive protein

WBC - white blood cell count

$\mathrm{RBC}$ - red blood cell count

PLT - platelets

AST - aspartate aminotransferase

ALT - alanine aminotransferase

ELISA - enzyme-linked immunosorbent assay

HSV - herpes simplex virus

Ig - immunoglobulins

EBV - Epstein-Barr virus

CMV - cytomegalovirus

RegiSCAR - Registry of Severe Cutaneous

Adverse Reactions

SCAR-J - Japanese Consensus Group.

HHV - human herpesvirus

TNF - tumor necrosis factor

PCR - polymerase chain reaction

\section{References:}

1. Sontheimer RD, Houpt KR. DIDMOHS: a proposed consensus nomenclature for the drug-induced delayed multiorgan hypersensitivity syndrome. Arch Dermatol 1998;134:874-6.

2. Phillips EJ, Chung WH, Mockenhaupt M, Roujeau J, Mallal SA. Drug hypersensitivity: pharmacogenetics and clinical syndromes. J Allergy Clin Immunol 2011;127(3 Suppl):S60-6.

3. Descamps V, Ben Saïd B, Sassolas B, Truchetet F, AvenelAudran M, Girardin P, et al. Prise en charge du drug reaction with eosinophilia and systemic symptoms (DRESS). Ann Dermatol Venereol 2010;137:703-8. [In French]

4. Buck ML. DRESS Syndrome. Pediatr Pharm 2012;18(11).

5. Leão RN, Barreto P, Leão RP, Ribeiro JV. Nitrofurantoin: cause of DRESS syndrome. BMJ Case Rep 2013;2013.

6. Shiohara T, Iijima M, Ikezawa Z, Hashimoto K. The diagnosis of a DRESS syndrome has been sufficiently established on the basis of typical clinical features and viral reactivations. $\mathrm{Br} \mathrm{J}$ Dermatol 2007;156:1083-4.

7. Choudhary S, McLeod M, Torchia D, Romanelli P. Drug reaction with eosinophilia and systemic symptoms (DRESS) syndrome. J Clin Aesthet Dermatol 2013;6(6):31-7.

8. Kardaun SH, Sidoroff A, Valeyrie-Allanore L, Halevy S, Davidovici BB, Mockenhaupt M, et al. Variability in the clinical pattern of cutaneous side-effects of drugs with systemic symptoms: does a DRESS syndrome really exist? Br J Dermatol 2007;156:609-11.

9. Bocquet $\mathrm{H}$, Bagot $\mathrm{M}$, Roujeau JC. Drug-induced pseudolymphoma and drug ypersensitivity syndrome (Drug rash with eosinophilia and systemic symptoms: DRESS). Semin Cutan Med Surg 1996;15:250-7.

10. Husain Z, Reddy BY, Schwartz RA. DRESS syndrome. Part II. Management and therapeutics. J Am Acad Dermatol 2013;68:709-17.

11. Chen YC, Chiu HC, Chu CY. Drug reaction with eosinophilia and systemic symptoms: a retrospective study of 60 cases. Arch Dermatol 2010;146:1373-9.

12. Descamps V, Ranger-Rogez S. DRESS syndrome. Joint Bone Spine 2014;81:15-21.

13. Halink DA, Marijnissen RM, Schut AA, Oude Voshaar RC. Drug reaction with eosinophilia and systemic symptoms induced by carbamazepine: DRESSed to kill. Gen Hosp Psychiatry 2011;33(4):412.e5-8.

14. Tetart F, Picard D, Janela B. Prolonged evolution of drug reaction with eosinophilia and systemic symptoms: clinical, virologic, and biological features. JAMA Dermatol 2014;150:206-7.

15. Kano Y, Hiraharas K, Sakuma K, Shiohara T. Several herpesviruses can reactivate in a severe drug-induced multiorgan reaction in the same sequential order as in graftversus-host disease. Br J Dermatol 2006;155:301-6.

16. Tohyama M, Hashimoto K, Yasukawa M. Association of human herpesvirus 6 reactivation with the flaring and severity of drug-induced hypersensitivity syndrome. Br J Dermatol 2007; 157:934-40.

17. Um SJ, Lee SK, Kim YH, Kim KH, Son CH, Roh MS, et al. Clinical features of drug-induced hypersensitivity syndrome in 38 patients. J Investig Allergol Clin Immunol 2010;20:55662. 
18. Chan JC, Chan HH, Yeung CK. Drug reaction with eosinophilia and systemic symptoms. Hong Kong J Dermatol Venereol 2012;20:163-70.

19. Kardaun SH, Sekula P, Valeyrie-Allanore L, Liss Y, Chu C, Creamer D, et al. Drug reaction with eosinophilia and systemic symptoms (DRESS): an original multisystem adverse drug reaction. Results from the prospective RegiSCAR study. Br J Dermatol 2013;169:1071-80.

20. Genin E, Chen DP, Hung SI, Sekula P, Schumacher M, Chang PY, et al. HLA-A*31:01 and different types of carbamazepineinduced severe cutaneous adverse reactions: an international study and meta-analysis. Pharmacogenomics J 2014;14:281-8.

21. Ganeva M, Gancheva T, Lazarova R, Troeva J, Baldaranov I, Vassilev I, et al. Carbamazepine-induced drug reaction with eosinophilia and systemic symptoms (DRESS) syndrome: report of four cases and brief review. Int J Dermatol 2008;47(8):853-60.

22. Choi HG, Byun J, Moon HC, Yoon JH, Yang KY, Park SC, et al. Allopurinol-induced DRESS syndrome mimicking biliary obstruction. Clin Mol Hepatol 2014;20(1):71-5.

23. Brown RJ, Rother KI, Artman H, Mercurio MG, Wang R, Looney RJ, et al. Minocycline-induced drug hypersensitivity syndrome followed by multiple autoimmune sequelae. Arch Dermatol 2009;145(1):63-6.

24. Lee JH, Park HK, Heo J, Kim TO, Kim GH, Kang DH, et al. Drug rash with eosinophilia and systemic symptoms (DRESS) syndrome induced by celecoxib and anti-tuberculosis drugs. J Korean Med Sci 2008;23(3):521-5.

25. Taylor JL, Kulkarni MS, Behringer EC, Yusufali T, Trento A, D'Attellis NP. Minocycline-induced drug reaction with eosinophilia and Systemic symptoms syndrome: myocarditis and multiple organ failure. ICU Dir 2012;3(3):139-43.

26. Wenk KS, Pichard DC, Nasabzadeh T, Jang S, Venna SS. Vemurafenib-induced DRESS. JAMA Dermatol 2013;149:1242-3.

27. Naisbitt DJ, Farrell J, Wong G, Deptta JP, Dodd CC, Hopkins JE, et al. Characterization of drug-specific T cells in lamotrigine hypersensitivity. J Allergy Clin Immunol 2003;111:1393-403.

28. Su-Yin AN, Tai WW, Olson RK. Lamotrigine-associated reversible severe hepatitis: a case report. J Med Toxicol 2008;4(4):258-60.

29. Naveen KN, Ravindra MS, Pai VV, Rai V, Athanikar SB, Girish M. Lamotrigine induced DRESS syndrome. Indian J Pharmacol 2012;44(6):798-800.

30. Božić K, Gebauer Bukurov K, Jovanović M, Vujanović Lj, Slankamenac P. Serious rash after prolonged use of lamotrigine - report of four cases. HealthMed 2011;5(2):409-12.

31. Ginory A, Chaney-Catchpole M, Demetree JM, Mayol Sabatier LM, Nguyen M. Drug reaction with eosinophilia and systemic symptoms (DRESS) in an adolescent treated with lamotrigine. J Pediatr Pharmacol Ther 2013;18(3):236-40.

32. Parri N, Bernardini R, Pucci N, Novembre E, Azzari C, Vierucci A. Drug rash with eosinophilia and systemic symptoms induced by lamotrigine therapy. Int J Immunopathol Pharmacol 2007;20:643-5.

33. Hussain N, Gosalakkal JA. Lamotrigine rash- a potentially life-threatening complication. Emerg Med J 2007;24:448.

34. Aouam K, Ben Romdhane F, Loussaief C, Salem R, Toumi A, Belhadjali $\mathrm{H}$, et al. Hypersensitivity syndrome induced by anticonvulsants: possible cross-reactivity between carbamazepine and lamotrigine. J Clin Pharmacol 2009; 49:1488-91.

35. Cacoub P, Musette P, Descamps V, Meyer O, Speirs C, Finzi L, et al. The DRESS syndrome: a literature review. Am J Med 2011;124:588-97.

36. Prevost P, Bédry R, Lacoste D, Ezzedine K, Haramburu F, Milpied B. Hypersensitivity syndrome with olanzapine confirmed by patch tests. Eur J Dermatol 2012;22:126-7.

37. Darlenski R, Kazandjieva J, Tsankov N. Systemic drug reactions with skin involvement: Stevens-Johnson syndrome, toxic epidermal necrolysis, and DRESS. Clin Dermatol 2015; In press. doi: 10.1016/j.clindermatol.2015.05.005

38. Brajon D, Trechot P, Waton J, Cuny JF, Schmutz JL, Barbaud A. Suspicion of a new cross-reaction between carbamazepine and olanzapine. J Investig Allergol Clin Immunol 2014;24(1):60-1.

39. Naranjo CA, Busto U, Sellers EM, Sandor P, Ruiz I, Roberts EA, et al. A method for estimating the probability of adverse drug reactions. Clin Pharmacol Ther 1981;30:239-45.

\section{Lamotrigin udružen sa DRESS sindromom - prikaz slučaja}

\section{Sažetak}

Uvod. Lekom izazvan odložen multiorganski sindrom poznat i pod nazivom DRESS (eng. drug reaction with eosinophilia and systemic symptoms), podrazumeva neočekivanu lekom izazvanu reakciju koja se klinički najčešce manifestuje visokom temperaturom, morbiliformnim osipom na koži i upalom jednog ili više unutrašnjih organa, uključujući jetru, bubrege i/ili srce, dve do osam nedelja nakon uključivanja leka u terapiju. Lekovi koji najčešće izazivaju ovaj sindrom su: aromatski antikonvulzanti, sulfa- derivati, antidepresanti, nesteroidni antiinflamatorni i antimikrobni agensi.

Prikaz slučaja. Prikazujemo slučaj četrdesetčetvorogodišnje ženske osobe koja od puberteta ima psihijatrijske tegobe. Sedam dana pre prijema na našu kliniku, javila se u Urgentni centar zbog visoke febrilnosti, intenzivnog neproduktivnog kašlja, nazalne sekrecije, otoka i crvenila lica i šaka. Rutinska laboratorijska ispitivanja ukazala su na blagu eozinofiliju od 6\% (referalne vrednosti $0-5 \%$ ). 
Pacijentkinji je savetovano da odmah obustavi uzimanje svih lekova, s obzirom da je mesec dana ranije lečena i otpuštena sa psihijatrijske klinike, gde je zbog paranoidnog personalnog poremećaja započeto lečenje sledećim lekovima: olanzapin (antipsihotik i blokator serotonina), lamotrigin (antiepileptik) i losartan (antihipertenziv, blokator angiotenzin II receptora). Zbog perzistirajuće febrilnosti i pogoršanja respiratornih simptoma i znakova, infektolog je postavio dijagnozu akutnog bronhiolitisa i u terapiju uveo azitromicin u dnevnoj dozi od $500 \mathrm{mg}$ tokom tri dana; rendgenski snimak pluća bio je u granicama referalnog nalaza, pa je pacijent upućen na pregled dermatologu.

Prilikom prvog dermatološkog pregleda, utvrđeno je prisustvo difuznog jako izrženog eritema i umerenog edema na licu i morbiliformnog eritema na koži ekstremiteta. I pored antihistaminika koji je uključen u terapiju, osip na koži se i dalje pojačavao i širio na ostale delove tela, tako da je na prijemu u bolnicu, pored difuznog eritema i edema lica, bio prisutan generalizovni lividni makulozni osip koji je zahvatao više od $50 \%$ površine tela sa tendencijom konfluencije, bez periferme limfadenomegalije (slike 1,2).

Laboratorijski parametri koji su na prijemu odstupali od referalnih vrednosti odnosili su se na povišen broj leukocita u krvi $(17,3 \times 10 \% / \mathrm{L}$, referalno 3,4-9,3 x $\left.10^{9} / \mathrm{L}\right)$, blagu limfocitozu $\left(5,67 \times 10^{9} / \mathrm{L}\right.$, referalno $0,8-4$ x $\left.10^{\%} / \mathrm{L}\right)$ i eozinofiliju $\left(2,38 \times 10^{\%} / \mathrm{L}\right.$ ili $13,8 \%$, referalno $0-0,5 \times 10^{9} / \mathrm{L}$ ili $0-5 \%$ ), povišene jetrene enzime u serumu i to aspartat aminotransferazu - AST (52 IU/L, referalno 0-35 IU/L), alanin aminotransferazu - ALT (136 U/L, referalno 0-35 U/L), povišenu vrednost amilaze u urinu (601 U/L, referalno 20-118 U/L), prisustvo u razmazu periferne krvi eozinofilije od 15\% (referalno $0-5 \%$ ), atipičnih limfocita $8 \%$ (referalno < $5 \%)$ i nezrelih mijelocita (1\%).

Dijagnoza DRESS sindroma postavljena je na osnovu prisustva prihvaćenih dijagnostičkih kriterijuma, uključujući osip na koži i sledeća odstupanja u kompletnoj krvnoj slici i osnovnim biohemijskim parametrima: leukocitoza ( $\left.>11 \times 10^{9} / \mathrm{L}\right)$, eozinofolija $(>1,5 \times 10 \%$ L), atipični limfociti (> 5\%), jetreni enzimi $($ ALT > $100 \mathrm{IU} / \mathrm{L})$, povišen nivo amilaze u urinu. Trećeg dana po prijemu i započinjanju lečenja, došlo je do poboljšanja vrednosti labortorijskih parametara: broj leukocita u krvi iznosio je $10,5 \times 10^{3} / \mathrm{L}$, eozinofila u diferencijalnoj formuli 8,8\%, AST je normalizovan i iznosio je $15 \mathrm{IU} / \mathrm{L}$, dok je ALT smanjen na $50 \mathrm{IU} / \mathrm{L}$. $\mathrm{Za}$ vreme sedmodnevne hospitalizacije, ordiniran je parenteralno metilprednizolon u dozi od $40 \mathrm{mg}$ dnevno i peroralno ranitidin, loratadin, butamirat citrat (antitusik) i losartan (antihipertenziv). Posle otpusta iz bolnice, nastavljena je terapija kortikosteroidima putem peroralnog unošenja prednizolona ( $\mathrm{u}$ dozi od $40 \mathrm{mg}$ dnevno sa smanjenjem dnevne doze za 10 mg svakih sedam dana), ranitidina i losartana. $\mathrm{Na}$ otpustu je na koži i dalje bio prisutan eritematozni makulozni osip. Tri nedelje kasnije, došlo je do normalizacije svih laboratorijskih prametara, dok je na koži i dalje perzistirao značajno bleđi, rezidualni, svetloružičasti makulozni osip (slike 3-6). Kožne promene su potpuno nestale na kontrolnom pregledu šest nedelja posle otpusta iz bolnice, tj. osam nedelja posle obustave uzimanja lamotrigina i olanzapina. $U$ terapiju je na predlog nadležnog psihijatra, ponovo uveden olanzapin koji je pacijentkinja nastavila da pije bez ikakvih tegoba.

Diskusija. DRESS sindrom klinički tipično karakterišu dug period 2-8 nedelja od prvog uzimanjaleka do pojave prvih simptoma, kao i prolongirani vremenski period od trenutka obustavljanja uzimanja leka, do potpunog povlačenja svih znakova uključujući i promene na koži. Pored visoke febrilnosti, limfadenomegalije i promena na koži, sindrom karakterišu i odstupanja u hematološkim i biohemijskim parametrima koja ukazuju na zahvaćenost unutrašnjih organa, najčešće jetre, bubrega, pluća, srca ili pankreasa. Iako promene na koži mogu progredirati od purpuričnih i pustuloznih, pa sve do eksfolijativnog dermatitisa, one mogu ostati u senci u odnosu na jako izražene simptome i znake zahvaćenih unutrašnjih organa, te zato „reakcija” umesto „raš“ označava „R“ u akronimu DRESS. Kod naše pacijentkinje, prvi simptomi su se javili mesec dana posle uvođenja tri leka, od kojih su dva bila psihoaktivna (olanzapin, antipsihotik i inhibitor preuzimanja serotonina i lamotrigin; antiepileptik i stabilizator raspoloženja, lamotrigin; treći lek je bio antihipertenziv losartan, iz grupe blokatora angiotenzinskih II receptora).

Iako tačan patogenetski mehanizam odgovoran za nastanak DRESS sindroma nije u potpunosti razjašnjem, radi se najverovatnije o idiosinkrazijskoj reakciji zasnovanoj na jednom $\mathrm{i} / \mathrm{ili}$ više od navedenih 
uzroka: 1) defekt u metabolisanju leka koji rezultira neadekvatnom eliminacijom toksičnih reaktivnih intermedijarnih produkata (npr. usporena acetilacija ili poremećana aktivnost arena oksidaze, enzima odgovornog za metabolisanje antikonvulzivnih lekova; 2) reaktivacija humanog herpes virusa-6 (HHV-6), humanog herpes virusa-7 (HHV-7), Epštajn-Barovog virusa (EBV), ili citomegalovirusa (CMV), koja može da pokrene reakciju imunskog sistema; 3) genetska predispozicija za poremećan imunski odgovor.

Evropska, RegiSCAR grupa istraživača (engl. The European Registry of Severe Cutaneous Adverse Reactions Group) i Japanska konsenzus grupa (eng. The Japanese Consensus Group), utvrdile su dijagnostičke kriterijume za DRESS sindrom: Inkluzioni kriterijumi koje je uspostavila RegiSCAR groupa izneti su u Tabeli 1 i oni služe za postavljanje dijagnoze DRESS sindroma, dok se na osnovu skoring sistema (ukupni skor se kreće od -4 do +9), vrši klasifikacija dijagnoze DRESS sindroma na definitivnu (ukupnii skor $>5$ ), verovatnu (ukupni skor 4-5), moguću (ukupni skor 2-3), ili se dijagnoza isključuje (ukupni skor $<2$ ).

Prema RegiSCAR kriterijumima, kod naše pacijentkinje su osim trombocitopenije i limfadenopatije bili prisutni svi ostali kriterijumi, koji su skorovani: eozinofilija $\left(>1,5 \times 10^{9} / \mathrm{L}\right)$ sa +2 atipični limfociti $(>5 \%)$ sa +1 , procentualna zahvaćenost kože $(>50 \%)$ sa +1 , osip koji ne isključuje dijagnozu DRESS sindroma sa +1 , poremećaj finkcije jetre $($ ALT > $100 \mathrm{IU} / \mathrm{L}) \mathrm{sa}+1$. S obzirom da je ukupni skor koda naše pacijentkinje iznosio +6 , dijagnoza DRESS sindroma kod naše pacijentkinje je bila defnitivna.

Prema kriterijumima Japanske konsenzus grupe za postavljanje dijagnoze DRESS sindroma, naša pacijentkinja je imala pet prvih od ukupno sedam kriterijuma, što je odgovaralo dijagnozi atipičnog DRESS sindroma (Tabela 2). U odnosu na kriterijume koje je dala RegiSCAR grupa, glavna razlika je što je u kriterijume Japanske konsenzus grupe uključena i reaktivacija infekcije sa HHV-6, što je u nedostatku dokaza o direktnoj ulozi herpes virusa u nastanku DRESS sindroma izazvalo kontroverzne stavove. U in vitro istraživanjima utvrđeno je da lek udružen sa pojavom DRESS sindroma, ne samo da pospešuje replikaciju HHV-6 i EBV virusa putem inhibicije epigenetskih kontrolnih mehanizama (dva glavna mehanizma su metilacija i histonska acetilacija), nego kod genetski predisponiranih osoba (npr. genetski polimofizam za citokine, receptore ili antagoniste, kao što je pokazano za TNF-receptor), pokreće i antivirusni T-ćelijski imunski odgovor putem interakcije sa receptorima glavnog histokompatibilnog kompleksa. Japanski kriterijumi su se istovremeno pokazali manje praktičnm, $s$ obzirom na mali dijagnostički značaj seroloških testova i potrebe za uključivanjem kvantitativne PCR u krvi, sa ciljem detekcije reaktivacije virusa.

Jetra je najćešće zahvaćen organ, a hepatitis, prisutan i kod naše pacijentkinje, može se javiti u preko $80 \%$ slučajeva, potom sledi zahvaćenost bubrega u $40 \%$, pluća u 33\%, kardiovaskularnog sistema u 15\% i pankreasa kao kod naše pacijentkinje u 5\% slučajeva. Najčešće opisani hematološki poremaćaji u DRESS sindromu su: povećan broj atipičnih limfocita (63\%), eozinofilija (52\%), limfocitopenija (45\%), i trombocitopenija (25\%). Kod naše pacijentkinje bila je prisutna: leukocitoza (> $11 \times 109 / \mathrm{L})$, eozinofilija (> $\left.1,5 \times 10^{9}\right)$ i povišen broj atipičnih limfocita (> 5\%).

Prognoza je je dobra ukoliko se na vreme isključi inkriminisani lek, iako je za postizanje kompletne remisije potrebno nekoliko nedelja, kao kod naše pacijentkinje, gde je do kompletne rezolucije bilo potrebno 8 nedelja.

Ukoliko su jače zahvaćeni unutrašnji organi, potrebno je u terapiju uključiti sistemske kortikosteroide u srednjim i visokim dozama, ali je potrebno prethodno isključiti postojanje infekcije. Ukoliko se pažljivo, tokom 6-8 nedelja smanjuje doza kortikosteroida, snižava se rizik od recidiva, što smo i mi sproveli kod naše pacijentkinje. Ukoliko se u terapiju ponovo uvede inkriminisani lek, simptomi se javljaju posle kraćeg vremenskog perioda od uključivanja leka.

Preko 40 različitih lekova među kojima su i lamotrigin i olazapin su u literaturi povezani sa razvojem DRESS sindroma, najčešće su to aromatski antikonvulzivi (fenitoin, fenobarbital, karbamazepin) i sulfonamidi, a potom slede i ostali kao što su dapson (DDS, 4,4-diaminodifenilsulfon), alopurinol, kaptopril, blokatori kallcijumovih kanala, ranitidin, talidomid, minociklin, nesteroidni antiinflamatorni lekovi, antituberkulotici, $\alpha$-metildopa i antiretrovirusni lekovi (abakavir, zalcitabin, nevirapin). Lamotrigin [6-(2,3-diklorofenil)-1,2,4-triazine-3,5-diamine] nearomatski je antiepilektik, koji ne pokazuje ni 
strukturne niti farmakološke povezanosti sa ostalim antiepilepticima kao što je to npr. karbamazepin. Lamotrigin može izazvati različite simptome i znake: osipe po koži uključujući i urtikariju, multiplu insuficijenciju unutrašnjih organa, DRESS sindrom, akutnu insuficijenciju jetre, kao i diseminovanu intravaskularnu koagulaciju. Egzantemi udruženi sa teškim opštim simptomima koji su izazvani lamotriginom, javljaju se najščešće unutar 6-8 nedelja od započinjanja lečenja, ređe nakon 12 nedelja, a po pravilu - nikad kasnije. U literaturi je do sada opisano nekoliko slučajeva DRESS sindroma izazvanog lamotriginom; drugi psihoaktivni lek koji je uzimala naša pacijentkinja je bio antipsihotik olanzapin. Za razliku od lamotrigina, u literaturi postoji veoma mali broj (oko pet), do sada objavljenih radova u kojima se pojava DRESS sindroma povezuje sa upotrebom olanzapina.

Dijagnoza DRESS sindroma kod naše pacijentkinje klasifikovana je kao definitivna; neposredni uzrok sindroma definisan je na osnovu skoring sistema koji je uspostavio Naranjo sa saradnicima, kao verovatna neželjena reakcija izazvana lamotriginom (finalni skor 7); mi nismo objektivno dokazali da je neželjena reakcija bila izazvana lekom, što se moglo učiniti da smo npr. sproveli kožne testove, koji su indikovani nakon određene vremenske distance od jednog do nekoliko meseci (zavisno od dužine terapije potrebne za kompletnu sanaciju svih simptoma i znakova DRESS sindroma). S obzirom da je lamotrigin poznat kao čest uzrok DRESS sindroma, za razliku od olanzapina, da među njima nema unakrsnog reagovanja, a imajući u vidu neophodnost njegove primene $\mathrm{u}$ datom trenutku, psihijatar je smatrao da $\mathrm{u}$ terapiju ponovo treba uvesti olanzapin. Mi bi za 6 meseci sproveli epikutano testiranje i postepeno ponovo uveli olazapin, kontrolisano, postepeno, u bolničkim uslovima. Iz tog razloga, možemo samo pretpostaviti da je lamotrigin direktno odgovoran za nastanak DRESS sindroma kod naše pacijentkinje, ali je za nju uzimanje ovog leka strogo kontraindikovano. Zaključak. Prikazujemo slučaj ženske osobe sa DRESS sindromom koji se povukao nakon prestanka uzimanja antikonvulzantnog leka lamotrigina i antipsihotika olanzapina, ali se na osnovu daljeg toka moglo pretpostaviti da je lamotrigin bio uzrok oboljenja.

\section{Ključne reči}

Sindrom preosetljivosti na lekove; Antikonvulzivi; Neželjena dejstva i reakcije na lekove; Antipsihotici; Prikazi slučajeva 